This article was downloaded by: [Temple University Libraries]

On: 08 January 2015, At: 02: 14

Publisher: Routledge

Informa Ltd Registered in England and Wales Registered Number: 1072954

Registered office: Mortimer House, 37-41 Mortimer Street, London W1T

3J H, UK

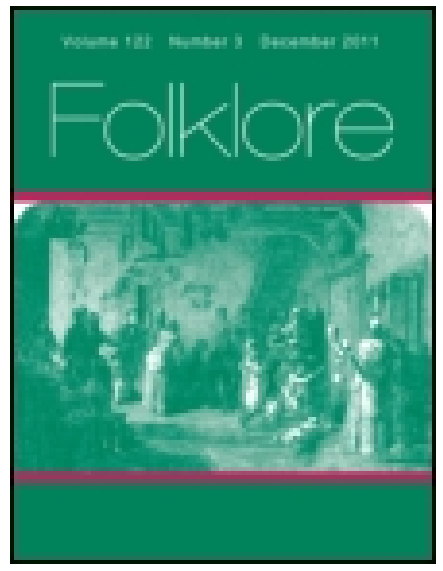

\title{
Folklore
}

Publication details, including instructions for authors and subscription information:

http:// www. tandfonline.com/loi/ rfol20

\section{An Anglesey Superstition : Modes of Protection from Evil Spirits.}

R. Gwynedon Davies

Published online: 01 Feb 2012.

To cite this article: R. Gwynedon Davies (1918) An Anglesey Superstition : Modes of Protection from Evil Spirits., Folklore, 29:2, 158-159, DOI: 10.1080/ 0015587X. 1918.9719048

To link to this article: http:// dx. doi.org/ 10.1080/0015587X.1918.9719048

\section{PLEASE SCROLL DOWN FOR ARTICLE}

Taylor \& Francis makes every effort to ensure the accuracy of all the information (the "Content") contained in the publications on our platform. However, Taylor \& Francis, our agents, and our licensors make no representations or warranties whatsoever as to the accuracy, completeness, or suitability for any purpose of the Content. Any opinions and views expressed in this publication are the opinions and views of the authors, and are not the views of or endorsed by Taylor \& Francis. The accuracy of the Content should not be relied upon and should be independently verified with primary sources of information. Taylor and Francis shall not be liable for any losses, actions, claims, proceedings, demands, costs, expenses, damages, and other liabilities whatsoever or howsoever caused arising directly or indirectly in connection with, in relation to or arising out of the use of the Content.

This article may be used for research, teaching, and private study purposes. Any substantial or systematic reproduction, redistribution, reselling, loan, sub-licensing, systematic supply, or distribution in any form to anyone is 
expressly forbidden. Terms $\&$ Conditions of access and use can be found at http://www.tandfonline.com/page/terms-and-conditions 


\section{The Praying Palm of Faridpur.}

CALCUTTA, 4th Fanuary. UNDER the presidency of Lord Ronaldshay Sir J. C. Bose delivered a lecture this evening on "The praying palm-tree."

Sir J. C. Bose said that perhaps no phenomenon was so remarkable and shrouded with greater mystery as the performances of a particular palm tree near Faridpur. In the evening while the temple bells rang calling the people to prayer the tree bowed down as if to prostrate itself, and erected its head again in the morning. This process is repeated every day of the year. The phenomenon had been regarded as miraculous and pilgrims had been attracted in great numbers. It was also alleged that offerings made to the tree had been the means of effecting marvellous cures.

The lecturer first obtained photographs of the two positions which proved the phenomenon to be real. The next thing was to devise a special apparatus to record continuously the movement of the tree day and night. The records of the palm tree showed that it fell with the rise of temperature and rose with the fall. The records obtained with other trees brought out the extraordinary and unsuspected fact that all trees are moving, such movement being in response to changes in their environ. ment.

Pioneer Mail, Allahabad, I Ith January, 1918.

\section{An Anglesey Superstition: Modeg of Protection from Evil. Spirits.}

For the following note the Editor is indebted to Sir James Frazer.

Twenty-five years ago an old man in one of the parishes of Anglesey invariably bore or rather wore a sickle over his neck -in the fields, and on the road, wherever he went. He was rather reticent as to the reason why he wore it, but he clearly gave his questioner to understand that it was a protection 
against evil spirits. This custom is known in Welsh as "gwisga'r gorthrem," which literally means "wearing the oppression." Gorthrwm $=$ gor, an intensifying affix $=$ super, and trem = heavy, so that the phrase perhaps would be more correctly rendered "wearing the overweight." It is not easy to see the connection between the practice and the idea either of overweight or oppression; still, that was the phrase in common use.

For a similar reason, that is, protection from evil spirits during the hours of the night, it was and is a custom to place two scythes archwise over the entrance-side of the wainscot bed found in many of the older cottages of Anglesey. It is difficult to find evidence of the existence of this practice to-day as the old people no doubt feel that it is contrary to their prevailing religious belief and will not confess their faith in the efficacy of a "pagan" rite which they are yet loth to abandon.

R. Gwynedon Davies.

\section{Sanctuaries and Fairies in Wegt Ireland.}

Mr. T. J. Westropp, who is doing excellent work on the investigation on scientific lines of prehistoric remains in Ireland, has republished from the Proceedings of the Royal Irish Academy (vol. xxxiv. Section C, No. 3) a paper of "The Ancient Sanctuaries of Knockaincy and Clogher, Co. Limerick." Here a cairn commemorates the cult of the goddess Aine, of the god-race of the Tuatha De Danann. She was a water-spirit, and has been seen, half-raised out of the water, combing her hair. She was a beautiful and gracious spirit, "the bestnatured of women," and is crowned with meadowsweet (spiraa), to which she gave its sweet smell. She is a powerful tutelary spirit, protector of the sick, and connected with the moon, her hill being sickle-shaped, and men, before performing the ceremonies, used to look for the moon-whether visible or not-lest. they should be unable to return. They used to comb the sheaves on St. John's Eve, carrying lighted wisps to bring luck 